\title{
The Rise of the 'Grand Entrepreneurs' in the Czech Republic and Their Contest for Capitalism*
}

\author{
VLADIMÍR BENÁČEK** \\ Institute of Sociology, Academy of Sciences of the Czech Republic, Prague
}

\begin{abstract}
It is argued in the article that the peaceful transition to capitalism in communist countries was not possible without the co-action of the nomenklatura, whose interest was to transform their informal access to state-owned capital into an authentic 'grand entrepreneurship'. The necessary acquisition of physical capital was achieved by means of mass privatisation schemes in which the nomenklatura took advantage of their social capital and information asymmetries. In the Czech case, there were three social groups competing for a position among the new entrepreneurial elite. The initially large gains of the nomenklatura gradually eroded when new businesses opened to domestic and international competition, where competitiveness depended on endowments of human (entrepreneurial) and economic capital. In the subsequent wave of ownership restructuring, initiated after 1994, the former nomenklatura was partially squeezed out of the tradable sector, which was occupied by better skilled foreign and domestic entrepreneurs. The exiting entrepreneurs converted their holdings into consumer goods, or defected to sectors less open to competition, where the alignment of social capital and bureaucracy persisted. Their position depends now on the pending reforms of public administration and the search for a more efficient social model.
\end{abstract}

Keywords: entrepreneurship, transition, ownership, forms of capital, social adjustment

Sociologický časopis/Czech Sociological Review, 2006, Vol. 42, No. 6: 1151-1170

\section{Entrepreneurs and capital}

The most important prerequisite for becoming an entrepreneur is the ownership of capital. [Kalecki 1954: 109]

The communist system of social organisation was indeed a system irreconcilably different from every stream of capitalism [Kornai 1992]. In comparisons of the two systems it is usually the economic approach that dominates over the political and

\footnotetext{
* This study was supported by grant no. 403/05/2769 from the Grant Agency of the Czech Republic for the project 'The Adjustment of the Czech Labour Force: Changing Job Structures, Wage Disparities and Work Orientations'.

** Direct all correspondence to: Vladimír Benáček, Institute of Sociology, Academy of Sciences of the Czech Republic, Jilská 1, 11000 Prague 1, Czech Republic, Vladimir.Benacek@soc.cas.cz

(C) Sociologický ústav AV ČR, Praha 2006
} 
the social. The diametrically different roles of capital, private property, factor markets, and competition between enterprises are what distinguish and set the tone of the institutions of capitalism and socialism that exist today.

Unfortunately, in contrast to abstract systems, a superficial observation of reality may lead to confusing conclusions once it is discovered that both systems were mixed [Samuelson 1967]. Therefore, some seemingly similar elements, like the existence of money, wages, private farming, and retail shops in socialist systems, and the existence of state firms or the tricks of relaxing hard budget constraints in capitalist systems [Maskin and Xu 2000], may evoke the idea of convergence. The comparison of real systems requires a multidisciplinary approach. The essential differences in economics should therefore be extended to politics (e.g. to the study of democracy) and also to sociology, which looks at the differences in social structures connected with capital ownership and entrepreneurship.

As the above quotation from Kalecki indicates, it is the ownership of capital that separates entrepreneurs from the owners of the labour force (including managers), who are hired by the former as wage earners. Nevertheless, even though the ownership of capital is a necessary precondition for becoming an entrepreneur, it alone is not enough. According to Marshall and Schumpeter, entrepreneurs are capitalists endowed with the capacity to organise and innovate, thus becoming the agents of constructive destruction as a crucial condition for economic development. According to Eswaran and Kotwal [1989], it is the role of entrepreneurs to act as decision-makers and risk-bearers in relation to capital yield, its reproduction and accumulation. Therefore, entrepreneurs are not merely passive nominal owners of capital (as, for example, some rentiers), but deliberately open their ownership position to the uncovered risk of its loss by allocating it to new innovative ventures.

The definition of an entrepreneur best suited to this study is Leibenstein's [1995] description of an entrepreneur as an agent endowed with capital and organisational, innovative, and managerial skills that allow him 'to make up for market deficiencies'. It is not the 'invisible hand' of the market but the minds of the very visible entrepreneurs who bear the burden of capitalism and extend its frontiers beyond the horizon. The more deficient the markets are, the more it is the entrepreneurs that must bear the toil and risk. Given that transition is characterised by deficient markets, entrepreneurship must be taken as a crucial factor of transition. This devilish 'detail' has been largely overlooked in economics because the assumption has been that markets are perfect and self-enforcing, and the entrepreneur is just a mediator between supply and demand. In contrast to axiomatic economics, management studies adhere more closely to the concept of Marshall and Schumpeter, which treats entrepreneurship as the fourth production factor. Given the markets, competition and private property, it is the entrepreneur alone who is supposed to orchestrate their synergy and generate the growth.

To apply a sociological perspective to this question, we can say that the core of authentic entrepreneurship is the ownership of economic (financial and physical) capital, but accompanied necessarily by cultural (human, entrepreneurial, ethical) 
capital, which facilitates the management of economic capital. As an auxiliary complement external to the market system, entrepreneurship can also be sustained by social capital [Eyal, Szelényi and Townsley 1998: 23]. Its role varies according to the market structure. If the markets are perfect, the role of social capital is low; if the markets are riddled with imperfections, its role rises sharply, to the point of incapacitating the market. In the literature, social capital is often referred to as network, relational or political capital. Its association with social hierarchies, politics, lobbies, and vested interests is obvious. In this study the subdivisions of three basic kinds of capital will be considered as synonyms.

The economic theory of specialisation based on the choice of effective inputs, so-called factor proportions theory, is intrinsically associated with the endowments of factors. According to the Heckscher-Ohlin theorem, an economic activity will incline towards efficiency in achieving its productive aims only if it is making more intensive use of a factor that the country is better endowed with relative to other countries [Jones and Kenen 1984]. Some more parallels can be found here. A change in the endowment in some factor (relative to others) is explained by the Rybczynski hypothesis, which implies that such a change will lead to a shift towards the provision of such commodities that use the growing factor more intensively. If applied to the case of high endowments of a country with relational capital (relative to devalued economic or human capital), we should expect a shift to those activities that depend on the use of such capital; for example, to the suppression of market-based competition and to a rise in competition based the mobilisation of bureaucratic clout and the use of crony-networks.

It is the ownership of economic capital that defines an entrepreneur, whose role should be contrasted with that of managers, who possess human capital only. Thus the managers must act as agents, that is, as the labour hired by the entrepreneurs, who act as principals [Pratt and Zeckhauser 1985]. We should also be able to distinguish between two levels of entrepreneurship - big and small. The grand entrepreneurs are thus large owners of capital holdings that employ hired labour, meanwhile the small entrepreneurs are small capital owners, who can just employ their own or their family's labour. From the legal point of view the grand entrepreneurs could be defined as statutory owners of limited liability companies or owners of controlling interest in joint-stock companies.

In this article we will concentrate on the evolution of grand entrepreneurs in a concrete transition country (Czech Republic). We will treat them as the leading social agents of capitalism - the socio-economic elite, in popular parlance referred to as 'the top hundred thousand'. Special attention will be devoted to the processes through which they emerged in the different stages of the Czech economic transition, including the phenomenon of the transformation of the former communist elite into the new elite of grand capitalists.

Kornai [2005] recently came out with one of the most informative studies of transitions. His analysis is unique for extending economic methodology into historical, social and political contexts. Kornai has characterised developments in Central 
Europe and China as 'an unparalleled success story', despite the 'many mistakes and disappointments'. It was unparalleled in historical comparison because it was complex (economic, political, social and legal) and internally and externally peaceful in nature, and it achieved its goals with unprecedented speed. In this article we will look at a similar theme of the drivers behind the transition, viewed through the prism of evolving entrepreneurship.

\section{Entrepreneurship and the end of central planning}

The fall of communism in Europe is often explained in a journalistic shortcut as a combination of three factors:

a) the total economic collapse in these countries;

b) a political collapse resulting from their surrender to the pressure of US military superiority;

c) civil resistance instigated by the emergence of dissidents as the recognised leaders of the public's craving for free markets and private property.

From the above it can be concluded that the communist system collapsed because of its total entrepreneurial failure, in terms of both economic governance and political governance at the levels of the communist party, the police and the military. That may sound logical given that, according to the strict definition of 'entrepreneurship', no entrepreneurs could exist in a society without private capital ownership. The liabilities of ownership rested with the impersonal State and the personal accountability of communist managers concerned only their wage contracts.

However, the absence of private capital could have been approximated by the existence of 'shadow' (informal) capital ownership under socialism, which allowed the incumbents to appropriate a part of the capital yield. Although such a system worked below economic optimum, its performance was considered 'satisficing', that is, not so low as to cause the system to break down. Historical observations of the period between 1917 and 1989 would tend to support this assumption. In other words, socialist quasi-entrepreneurship allowed the system to survive even the kind of economic and political blows that would otherwise have brought the capitalist system to a collapse.

At the same time, the third of the three factors listed above could be interpreted as a kind of 'entrepreneurial' victory, wherein civic organisation and dissident leadership outperformed the State. This would imply that while the communist system was devoid of entrepreneurship, the skills of entrepreneurship were developing in the communist opposition. Unfortunately, as discussed, for example, by Kornai [2005], this wishful conclusion is counter-factual. The communist dissident opposition was generally marginal - more a symbol of hope than an organised force. Even in its most visible manifestations (like in Poland in the 1980s) it would not have had the strength to overcome the combined forces of internal and external communist power on its own. 
Even though the failures of communist economic management everywhere were very serious, the system of its half-blind central command should have been able to achieve political integrity, the supply of basic consumer and investment goods, an influence over developing countries, and a strong military and police deterrent to opposition and secure the continuity of communist rule - provided those were the shared aims of the nomenklatura elite. ${ }^{1}$ Surprisingly, it was not the case. The bottom line is that the massive abandonment of the communist economic system cannot be explained as a result of just an offensive onslaught from the trenches of external and internal opponents. There must have been co-action on the other side, too.

What first launched the transition in communist countries were the pro-market reforms, however superficial and non-capitalistic these attempts at goulash communism may have been. These experiments created openings for clandestine progress towards a socialist 'entrepreneurship' at all levels of the economy, including central planning. The nomenklatura was then able to reinforce its long-held status as a class of privileged bureaucrats by conferring entrepreneurial tasks on itself. The 'old guard' of the nomenklatura then gradually resigned, as if it were obvious that central planning, public property, and totalitarian 'democracy' were a dead end [Kornai 2005].

Within two years since the fall of the Berlin wall in 1989 this constellation of domestic strain resulted in an escalating series of political collapses unparalleled in human history. These coups, achieved so easily, were named 'velvet revolutions'. Since the hypothesis that the communist nomenklatura were completely overpowered from without has been rejected, the motives for dismantling communism and the agents behind them must be explained.

I will analyse this contest for control over the reins of economic power from a sociological perspective by examining the social structures of entrepreneurs and test the hypothesis that the communist nomenklatura in managerial positions had a tempting incentive to become the new entrepreneurs. An alternative approach would be to study the changes in political positions, as was done by Machonin et al. [2006: 53-68]. They also contained an element of entrepreneurship. Both perspectives overlap and reflect similar processes and outcomes.

The massive involvement of the nomenklatura in privatisation in all transition countries suggests that it was not by chance. It was privatisation that elevated the nomenklatura to the status of real entrepreneurs, notwithstanding the paradox that it meant they accepted capitalism. This explains why the fight for ownership through privatisation became such an obsession in post-communist economies and why the more natural approach of building an authentic private sector by supporting de novo firms, as occurred in China, was not adopted [Sato 1995]. My hypothe-

\footnotetext{
${ }^{1}$ In this article 'nomenklatura' refers to non-dissident political, economic, and cultural elite under the communist system. We will concentrate predominantly on the economic (managerial) elite, distinct from the political (apparatchik) elite.
} 
sis is that communist governance could not exist without some islands of entrepreneurship and with them the dormant acceptance of capitalism was also present.

Running the communist system required a great deal of entrepreneurship - to survive, its management had to work through and overcome chaotic information about cost efficiency, and the structure of the gluttonous final demand had to be ranked by priorities, which were all in conflict. Managers were therefore required to compensate for many of the market's deficiencies and engage in entrepreneurial behaviour, as described by Leibenstein [1995]. But what kind of entrepreneurship would this be? Baumol [1990] provides a clue, noting that human entrepreneurial activities are present in all societies. The creation of entrepreneurial capital is a part of human nature and it develops in all circumstances, even if its instruments are constrained. The problem different civilisations face, therefore, is to determine under what incentives and in which alternative economic fields (productive, redistributive or destructive) entrepreneurship is to be allocated.

Baumol's classification distinguishes between the Marshallian-Schumpeterian concept of productive entrepreneurship on one hand and its redistributive or destructive alternatives on the other hand. The crucial role is then played by market institutions, which must provide incentives preventing entrepreneurs from getting engaged in redistributive, predatory or destructive ventures. The initial inclinations of early communist 'entrepreneurship' aimed excessively at exploitative, redistributive, and destructive [!] activities were gradually curbed by the post-Stalinist reforms. Therefore, however bizarre the organisation of the communist economies may have been, there was also some amount of entrepreneurship to be found in them, regardless of the fact that the private ownership of capital was strictly limited.

\section{The social structure of entrepreneurship under communism}

Motivations towards entrepreneurship in the formerly Soviet-dominated countries have two sets of roots: capitalist and communist. As to the former, Central European countries were able to rely on the cultural principles on which their societies had been based two or three generations earlier. In 1948 Czechoslovakia had the most competitive economy in Central Europe [de Ménil and Maurel 1993; Benáček 2003]. The legacy of capitalism and recollections of self-reliance were most useful in situations where the workers had to resort to moonlighting and bartering to support themselves. This penurious situation was a result not just of the shortage of goods but was also due to the fact that employment in the nomenklatura hierarchies was not open to everyone on the basis of talent.

Also, the national stock of human (entrepreneurial) capital could not be fully used in the official economy, so business skills remained largely outside the nomenklatura, where they were used either in retail trafficking or in an informal system of providing friends with do-it-yourself services or items in exchange for services and goods in kind. The entrepreneurial skills of the shadow economy were often frit- 
tered away by high transaction costs on the exchange side and by limited access to technology. Nevertheless, these activities were a valuable form of entrepreneurial training that could be useful once small business was liberalised. Due to internal barriers, which varied in nature between sectors and regions, the legacy of capitalist entrepreneurship in communist countries was spread asymmetrically throughout society. This had a serious impact later on.

The legacy of 'communist entrepreneurship' affected state bureaucrats and party apparatchiks (together the 'nomenklatura'), who also had to invent the most bizarre tricks in order to force the unviable system of central command to perform. It was not altruism, but a motive for achieving their private 'residual claimancy' (i.e. rents), which actually brought their activity close to entrepreneurship. The Brezhnevian style of corporate management required personal initiative and innovation, however absurd they were in both process and outcome. The management of enterprises had two options: either to focus inwardly by pursuing efficiency or outwardly towards negotiations with vertically superior bureaucracies.

Given the known lack of microeconomic rationality in the system of central planning [Hayek 1935], the management of efficiency and innovation could only rely on some rudimentary principles, such as minimising queues, saving on material input and labour, or copying the products and processes used in market economies [Kornai 1980]. As for the outward focus, the objective was to bargain for a softer output plan or a higher quota of inputs. The latter was a sophisticated entrepreneurial treat, where the gains were high, and they could be used to build up of powerful private relational capital [see Bezemer, Dulleck and Frijters 2003; Blanchard and Kremer 1997].

As the opportunities for official (and unofficial) accumulation of wealth widened, socialist millionaires began cropping up everywhere, starting in the 1970s. If this quasi-entrepreneur fulfilled the plan target and showed sufficient loyalty to superiors, he/she received a free hand to exercise power over resources, staff policy, and bonus remuneration in the economic unit he/she oversaw within the hierarchy. On the same horizontal level of hierarchical bureaucratic subordination this manager had the power to collude with other 'partners' to form cartels, information asymmetries and political coalitions, which liquidated potential interference in the production, distribution or planning processes. As it gradually and naturally progressed, central planning evolved into a system in which agents and informal coalitions in the productive lower ranks of the command hierarchy controlled their principals in the upper command of formal subordination [Mlčoch 1990].

The resulting socio-political antagonism caused by different relationships to entrepreneurship can be identified with three social groups. Based on analysis from previous studies [Benáček 1994, 1995], we will refer to them here as 'marketeers', 'nomenklatura' and 'outsiders':

(i) Marketeers: private farmers, repair workers, artisans, tradesmen; catering and hotel staff, cab drivers, foreign exchange touts, greengrocers, used car dealers; shop managers, shop assistants, stock keepers; entertainers, artists, top sportsmen; ad- 
ministrators of queues, bureaucrats issuing licences, certificates and permits; crime ringleaders, etc.

(ii) Nomenklatura: directors of companies, their deputies, heads of divisions or financially independent units; paid party apparatchiks, high-ranking bureaucrats at ministries, district and municipal councils; high-ranking officers in army and police.

(iii) Outsiders: people with a low degree of revealed evident entrepreneurial aspirations, active mainly in the 'do-it-yourself' activities. However, there was a large middle-class sub-group with cultural capital among their ranks: doctors, engineers, teachers, computer operators, scientists or clerks, whose entrepreneurial skills could not be used under the communist system.

\section{The mechanism of communism's demise}

Even though each of the thirty-one post-communist countries in Europe and Asia had a different mixture of conditions leading up to the transition, the processes in the countries of Central and Baltic Europe converged towards very similar outcomes. The crucial factor in the demise of communist socio-economic organisation can be found in the internal demand for the trinity of freedoms that the communists could not provide:

- civic freedom (like freedom of speech and travel),

- political freedom (democracy),

- economic freedom (free enterprise and private property).

While the communist opposition comprised of the outsiders called for the first two freedoms, it was the communist economic elite that realised the potential for transforming their informal access (quasi-ownership) to state-owned capital into formally legal ownership of economic capital. The instruments for doing so lay in their dominant 'ownership' of relational capital and in the use of their better access to cultural (human and entrepreneurial) capital [Sik 1993]. This kind of development is in line with the concept of capital conversion elaborated by Bourdieu [1985], and later applied in the analysis of the transition of Czech elites [Matěju and Lin 1995; Večerník 1996; Eyal, Szelényi and Townsley 1998]. The public's daily encounter with the surrounding Western culture and businesses, the dual roots of entrepreneurship, and the elite's possession of three types of capital combined to offer the people a vision of transition to all three freedoms. However, in connection with transition each social group had a different target and different prerequisites, though they were all able to agree that some kind of transition should be undertaken and to act in accord.

The role of indigenous elites with entrepreneurial expectations in domestic political shake-outs is therefore obvious. It was essential for maintaining their medium-term objectives that they avoided any violent confrontation of power with other social groups - their potential allies. All of them were aware of that. Thus, with the exception of Yugoslavia, the transition of power proceeded without any large-scale 
armed intervention. In exchange, the communist nomenklatura did not lose their access to the processes of privatisation, entrepreneurship and political change in any of the transition countries [Benáček 2001; Winiecki, Benáček and Laki 2004].

The co-action of domestic elites from the ranks of the nomenklatura during the early phases of the peaceful dismantling of communism was essential because elites are more efficient in organising collective action than the loosely organised public. The ownership of human and social capital by the nomenklatura became a valuable contribution: it restrained the risk of economic breakdown and guaranteed a smooth break-through. Thus the transition countries were able to muster new economic leaders very quickly and without losses resulting from internal squabbling.

The strategy of converting the abundant endowments of social capital of the nomenklatura into new endowments of economic capital was a rational one, especially in societies trapped in a situation of 'building capitalism without capital' [Eyal, Szelényi and Townsley 1998]. Economic capital, as a condition of new entrepreneurship, had to be acquired in exchange for something else that already existed: foreign financial capital, domestic human capital, or domestic relational capital. This was the crucial crossroads in all post-communist transitions. The result depended on the bargaining power of these three capitals. Unsurprisingly, relational capital has shown the highest practical operability in almost all initial business encounters. That explains why both the emphasis the new Czech governments placed on large-scale privatisation (e.g. with vouchers or insider sales) and the 'Czech path' of privatisation (i.e. without much competition from abroad) was perfectly compatible with the aims of the nomenklatura.

The communist social system was full of long-suppressed and accumulated conflicts, which had to be addressed to find a new equilibrium. An immediate explosion of these conflicts and any attempt to eliminate the past elite would have unleashed chaos in society for a long time to come. Other transitions in the preceding century, filled with victims and lasting for generations, provided some valuable historical lessons. A peaceful transition has to be gradual, and that made co-action with the outgoing power essential. The whole process of the subsequent social, economic and political transformation could not be achieved by means of revolutionary commands but through step-by-step negotiations at the micro-level. This can be likened to a process of market tâtonnement, as described by L. Walras, and to the process of bargaining to settle property rights, as explained by Coase [1960]. It is the quest for reciprocal re-adjustments among millions of domestic agents looking to reallocate their diverse interests and capacities. It would therefore be a mistake if some domestic central authority or intervening external force were to mastermind and dictate the course of these complicated processes. ${ }^{2}$

\footnotetext{
2 Such failing examples can be found in the US interventions in Iraq and Afghanistan or in the external imposition of reforms during the German unification. A successful example can be found in China.
} 
Settling local inter-human relationships that had been fettered for decades had to be left to local negotiations in an environment of centrally secured non-violence. Surprisingly, these originally highly improbable gradual readjustments occurred independently in all post-communist countries. It happened despite the myriad of local trials and errors, missed chances and moral compromises that affected nearly everyone and disappointed the expectations of instant 'justice'. It was clearly a strategy of second best that can be criticised for its seeming blindness. Nevertheless, this amazing process of social tâtonnement, a social parallel to market clearing, in which the resolution of human conflicts could be fine-tuned gradually and in peace, became, in the end, a strategy more efficient than any exogenous social engineering. As Kornai [2005] pointed out, the transition was, after all, still extremely fast and unprecedented in human history.

The gradual contest for capitalism was the most characteristic feature of the evolution of entrepreneurship, especially in the crucial field of capital redistribution and ownership, where human conflicts were traditionally most violent. Thus the peaceful evolution of entrepreneurship, intertwined with the necessary ownership changes, can be regarded as the cornerstone of post-communist transition. The Czech lessons of the Velvet Revolution and then the 'velvet divorce' of Czechoslovakia are of particular interest in this respect.

The Czech transition was ready for launching long before the external threat from the Kremlin was lifted in 1983. The first signs of it had already emerged in the Prague Spring in 1968. However, news from Warsaw, Budapest and Berlin in the late 1980s was essential to confirm that the local transition would not be isolated. The power-game of triggering the transition and its consequences were thus in the hands of the three groups mentioned above - the marketeers, nomenklatura and outsiders, each of which had their own motives for change. Their entrepreneurial skills and expectations in particular were the crucial factors that drove the transition process [McMillan and Woodruff 2002]. When the window-dressing of central planning and hierarchical subordination finally lost its institutional support at the end of 1989, enterprises and the economy initially barely registered any change: the 'shadow management systems' were already in control of the economy and ready for transition [Benáček 1994, 1995].

We could ask how the nomenklatura 'triggered' the non-violent transition or how the various actors reached agreements over all the trade-offs that had to be resolved? Was there not some sort of deliberate and purposeful planning involved? These questions are incorrect, because they presume the existence of a centralised command. The series of subsequent collapses was not planned in the Kremlin or the White House, just as no central authority masterminded the decline of feudalism and the advancement of capitalism. Evolutionary processes (e.g. the Darwinian evolution or even market clearing) proceeds through gradual adjustments without being guided by any pre-agreed strategy. The abandonment of communism was a spontaneous development in the minds of the masses of agents, including their elites, who realised that change would not expose them to unbearable risks, and 
could even bring them new opportunities. Although the transition was tougher and more roundabout in both procedure and outcome than the majority of actors assumed, the basic idea was well founded and easily recognisable to anyone. The 'triggering' could then commence with any major social shake-outs. The fall of the Berlin wall acted like a fuse, its charge being an optimal critical mass, setting off a chain of shake-outs all over the world.

\section{Entrepreneurship in the early stages of transition}

As mentioned above, it was the nomenklatura in state monopolies and not the bureaucrats of central planning who were in control of the official parts of the economy and who gained even more power when Gorbachev's glasnost undermined the instruments of totalitarian coercion. These national systems were ready for the series of subsequent transitions that occurred once a strong external shock cracked the institutional braces in just one country. There was risk and uncertainty in particular cases, but on the premise of a gradual adjustment and the truce set up through the Velvet Revolution the nomenklatura was not at risk of losing much as a group. The advantage derived from their social capital endowment was unrivalled. The marketeers were in a similar situation: they expected a better deal once their activities were liberalised, having obtained an advantage in the accumulation of financial resources.

The outsiders appeared to gain least out of their initial entrepreneurial endowments, and their gains from the transition were originally associated with higher consumer choice and the introduction of democracy. Here a distinction should be made between outsider elites (cultural and technical intelligentsia) and the rest of the outsiders. The cultural intelligentsia had a jump-start in the beginning, when the mission of building the new institutions of democracy, education and the economy was placed on their shoulders. However, this mission was gradually outshone in importance by other, more practically oriented tasks of property redistribution and the political power struggle once privatisation issues began to dominate the stage after 1992. The initiative in building institutions thus shifted more towards the nomenklatura.

The technical intelligentsia endowed with human capital was offered better entrepreneurial opportunities, even though not immediately in large businesses, since their starting position directed them mostly to the small (self-employed) businesses. For example, 21\% of all Czech employees were registered in self-employed businesses by 1993. In 2003 that figure grew to 33.8\%. ${ }^{3}$ Also in other Central European and Baltic countries the increase in the number of self-employed was high and comparable to the situation in traditional market societies [Selowsky and Mitra 2002]. The growing number of small entrepreneurs must obviously been made up

\footnotetext{
3 According to the Czech Statistical Office, Annual Yearbook, 1996 and 2004.
} 
mostly of those outsiders with some endowments of human capital. Although the technical intelligentsia had delayed access to higher positions, its penetration into the ranks of entrepreneurs accelerated after the mid-1990s.

While the outsiders began to catch up with the others, their ascent had another unexpected outcome, as they clashed with the private sector that had already been established under socialism, i.e. with the marketeers. A similar situation was observed in Poland [Winiecki 2000; Winiecki, Benáček and Laki 2004]. The lack of vision and flexibility on the marketeers' part made them unable to withstand the competition from the new business start-ups emerging out of the former 'outsiders', and this caused the old private sector to shrink by $40-75 \%$. A similar observation of constructive destruction was reported in other countries [Gábor 1996; Eyal, Szelényi and Townsley 1998]. This suggests the general hypothesis that the socialist marketeers ultimately did not possess adequately competitive skills and relational endowments to make a smooth transition into the ranks of the new grand entrepreneurs.

Unfortunately, there are very few surveys that have studied the structure of Czech entrepreneurs by social group and origin, although some information is provided in a study [Benáček 2007] on the origin of Czechoslovak entrepreneurs who were registered as owners of big businesses in 1990-1992. Their structure was classified according to their highest working position achieved anytime during their careers prior to 1990. The most important findings include:

a) The probability of someone having been a communist bureaucrat and a top or middle management position and being in the emerging class of 'great private capitalist entrepreneurs' is very high $(46.3 \%)$.

b) Approximately $37-42 \%$ of the Czech emerging 'grand capitalists' in 1992 were people associated with the Communist Party. ${ }^{4}$

c) The rate of transition of former low-ranking state managers and supervisors into big new private businesses is very high, forming $44 \%$ of the total number of new grand entrepreneurs.

d) Only a small fraction of people (1.1\%), who were neither engaged in the communist nomenklatura networks, nor in any formal managerial position, have after three years succeeded in becoming grand entrepreneurs.

e) The chances of outsiders with human capital becoming 'great entrepreneurs' is only $2.5 \%$, which is still below the national average of $3 \%$. However, the probability of such a transition occurring among the group of unskilled outsiders is even lower - at merely $0.4 \%$.

Outsiders were held back in their ascent into entrepreneurship owing to their lack of initial wealth, owing to their exclusion from the power of the crony networks, and owing to the effects of discriminatory processes of adverse selection un-

${ }_{4}^{4}$ This estimate agrees with the conclusions of Matějů [1997] and Machonin et al. [2006: 45, $79]$, where the latter estimate the share of former nomenklatura among the grand entrepreneurs at $36.8 \%$ for 1994 , without distinguishing between the high and middle ranks. 
favourable towards people with high moral principles. However, the outsiders and low-ranking communist managers were not completely cut off from opportunities. They had access to small businesses and self-employment. The pressure from hard budget constraints was stronger these than in large (privatised) businesses, supported by special government policies [Winiecki, Benáček and Laki 2004]. Nevertheless, in the Czech case they made significant progress in efficiency and obtained a high share in the market in the late 1990s, which became a springboard for future expansion to become larger firms.

Other quantitative empirical studies have also looked at the origin and performance of the new Czech entrepreneurs. Matěju [1993a: 86] concluded that being a member of the nomenklatura resulted in 'far higher chances to enter the group of entrepreneurs' mainly due to the role of the network capital accumulated in the past. This was the driving force that triggered the transition and led to the early success of the nomenklatura. Three mechanisms were involved. The first and most important was the comparative advantage of the nomenklatura in terms of its endowment of social capital, which provided it with enough confidence to counter the power of the opposition. Then there was the complementary advantage of nomenklatura in both managerial and human capital. Modern society needed these resources; they were scarce and without substitute.

The third mechanism, albeit a minor one, was the greater wealth (savings) of the nomenklatura compared to the outsiders. This fact was confirmed in another study by Matěju [1993b], in which entrepreneurial success was measured by income levels. A high statistical significance was found for such exogenous variables as income in 1989, accumulated property before 1990, and a person's prior position in the hierarchy of the nomenklatura. Nevertheless, the study also confirmed the significance of factors such as education and professional commitment to the job, both of which demonstrated that the outsiders were not deprived of chances for entering entrepreneurial ranks later. Thus the fulfilment of entrepreneurial visions for a person endowed with ownership of capital of any kind was not beyond reality.

\section{The changing structure of entrepreneurs in the later stages of transition}

Since the start of the transition, the Czech government has made the transfer of property relatively easy because more than one-half of all national physical capital was offered for privatisation between 1991 and 1995. That gave an unparalleled boost to the growth of large businesses, which favoured not only those social groups better endowed with social capital but also foreign investors with high financial capital. The path-dependency of the capitalist future on the communist past was not severed abruptly but rather steadily diminished. The competition for property in a situation where information asymmetries, insider trading, moral hazard and weak ethics dominated over economic and human capital could not last forever. The access to property in such an opaque environment was biased, inefficient and pressed 
to a discriminatory selection of its elite by a mechanism of adverse selection, explained by Akerlof [1970]. That was a serious social threat.

National development depends very much on the national elite. An adverse selection of elites can undermine the national ability to act autonomously in the world and shift its politics to a sort of defeatist autarchy. It is possible to distinguish between the economic, political and cultural elite in relation to three kinds of capital. In a globalised world, the existence of a strong indigenous economic elite generates the externalities of national leadership able to compete internationally, to confidently uphold national culture, and to resist the ideologies of nationalism, communism and other extreme movements.

In the Czech case, the high-ranking nomenklatura's aim of easily defecting into the entrepreneurial class proved viable from the start of the transition [Možný 1991]. However, there are reasons for its diminishing returns. The basic argument is that while both economic and human capital are of crucial relevance for entrepreneurial performance in functioning market economies, the relational capital, as a factor of market distortion, has a minor role when the economy matures [Eyal, Szelényi and Townsley 1998]. Building capitalism by means of dominant relational capital had the drawback of sub-optimal economic performance. So the progress of the transition in the Czech Republic - establishing a market economy - was detoured by incompetent entrepreneurship, unsustainable property holdings, frauds, profits derived from implicit subsidies, decision-making intertwined with state bureaucracy and market competition impeded by government intervention. The result was the economic crisis in 1997-1999 when real GDP fell by 1.3\%. The macro-economic misalignments were not the cause but a concomitant effect.

Most of the property distribution completed in the second wave of voucher privatisation in 1994 was unsustainable and had to be redistributed. This required a subsequent series of Coasian contract renegotiations, whose outcomes were Paretoimproving. A new round of selection started on the markets that had already moved from excess supply to excess demand. All new owners (including the inexperienced or incompetent ones) were consequently exposed to competition with other indigenous entrepreneurs, foreign businesses, and imports. At the same time the share of imports to GDP reached $60 \%$ in 1997, while the value of the Czech crown appreciated steadily. Many entrepreneurs saw a bleak future themselves and abandoned their sinking ventures by shifting the costs to someone else. Thus the 'optimum' strategy for failing entrepreneurs became the practice of taking advantage of widely neglected property rights. 'Tunnelling' (i.e. stripping the assets of the company, its clients, banks, or public budgets) became a technique of enrichment compatible (or even commensurate) with their entrepreneurial comparative 'advantages'. The redistributive nature of a large part of the Czech new elite was then fully revealed.

The same logic that determined the selection of the Czech old-new entrepreneurs also meant that the defaults in property rights had to stay, becoming paradoxically a firm part of the game. If the visible hand of the law had been suddenly enforced, the gradual process of peaceful transition would have turned into a vi- 
cious crisis. The hazardous laws of relational capital would have to be re-installed as a dominant power, undermining the growing importance of economic capital.

Tunnelling certainly resulted in social losses, but it allowed inefficient entrepreneurs to reap the fruits of access to ownership and transform a part of their windfall economic capital into consumption and speculative assets. Even though a part of their (and the national) productive capital was thus liquidated, some capital was still able to find its way into the hands of new owners, who used it more productively. However, stricter property rights, rules and efficiency-enhancing institutions had to be gradually installed because the demand for them grew in strength. Thus the structure of ownership kept converging to Pareto-optimality by means of Coasian negotiations.

In the Czech case approximately $60 \%$ of new grand entrepreneurs were not from the ranks of the nomenklatura and the importance of human capital was not completely eliminated [Benáček 2007]. Entrepreneurially oriented outsiders were also able to acquire the capital relinquished by the initial inefficient owners. When the inflow of foreign investment intensified in 1995, the balance of economic power shifted. In 2002 foreign owners controlled approximately one-half of the productive physical capital in the country. The call for a substantial overhaul of the legal system and judiciary received a boost from the EU requirement that the country adopt the acquis communautaire before accession. At the same time the Czech government had to dismantle the system of 'banking socialism', whose bad debts (32\% of all credit in 1999) brought it to collapse. Consequently, practically all commercial banks had to be sold to foreign owners. Banks and market competition became the most important instruments pushing for enterprise efficiency.

The process of 'velvet transitions', unique in human history, required at least two stages, each of which had different rules and involved different capital to determine its functioning. This approach is an extension of Eyal, Szelényi and Townsley's seminal idea [1998] that social systems can be classified by the dominance of different types of capital. In the first stage of the Czech transition it was the dominant use of social capital accumulated during communism. In the second stage the dominance was marked by the steady rise of markets requiring economic capital. In reference to Kalecki's maxim quoted at the opening of this article, it was only at this stage that the entrepreneurs were able to acquire the status of authentic entrepreneurs and finally managed to become the owners of assets secured by law. It is worth speculating about whether the transition requires a third stage to reach completion, in which human (cultural) capital would move into the dominant role [Matějů and Vitásková 2006].

More recent studies have reached similar conclusions, confirming that the oldnew elite of the former Czech nomenklatura and the marketeers from the first stage of the transition were not always selected on the criteria of the first best. Their position was unsustainable as society moved into the second stage of the transition and the rise of the market, competition and efficiency-enhancing institutions of capitalism. In the Czech case this stage has been under way since 1994 until now. The 
new process of entrepreneurial restructuring was marked by the growing importance of economic and entrepreneurial capital. For example, Tuček [2006: 79] reported that during 1994-2004 "the share of the old-new elite sharply decreased". Another study [Machonin, Tuček and Nekola 2006: 544] also concludes: "... the gradual generational change in favour of younger and, in terms of education and/or fresh experience, better qualified cadres: all this ... led in the final years of the 20th century to the downfall of an important part of the economic old-new elite recently discredited in the new environment of society". "A genuine top business elite has emerged in the Czech Republic, one that in principle differs little from its Western counterparts" [Ibid.: 552].

Laki and Szalai [2006] reached a similarly upbeat conclusion, noting that the stabilisation of indigenous grand entrepreneurs in Hungary in the late 1990s is reason to set aside concerns that the transition in post-communist countries may have undermined national integrity by depriving them of the ability to compete internationally. The majority of indigenous grand entrepreneurs of 2005 typically started out as small businesses.

The 1989-2004 transition period was a productive time in the Czech Republic and the country made evident progress in economic and social organisation. The changes in the nature of entrepreneurship were particularly complicated owing to several transitional stages in the acquisition of capital. The sectors of internationally tradable commodities became highly competitive, as it was integrated into world markets. The importance of both economic and human (entrepreneurial) capital significantly increased, as the links between relational capital and domestic hierarchies began to weaken, often to the point of irrelevance. These were replaced with links to international capital, marketing networks and oligopolistic leaders.

Many domestic entrepreneurs that had emerged in the early stage of transition were forced to sell their ventures to international capital and/or exit from the business sector completely [Djankov 1999]. Most of them were from among the former nomenklatura. Nevertheless, the number of Czech businesses, registered as jointstock or limited liability companies, did not decrease, and all statistics have documented the rising number of entrepreneurs. There are two explanations: new entrepreneurs entered the scene and there was a defection to less competitive sectors, such as internationally non-tradable services, with fewer budget constraints and less competition. Some of these sectors were not forced to leave the stage of no or formal privatisation (e.g. in health care, energy supply or education) and many could continue to rely on help from public budgets and collusion with political parties and state bureaucracy [Matějů, Schneider and Večerník 2003]. The nature of this entrepreneurship does not differ so much from what it was like in the communist period. The role of relational capital is paramount for their survival, leading to deep corruption and practices enabled by too little or too much of regulation.

The oversized government sector and its impotent surveillance over the provision of public goods, which make up approximately $40 \%$ of the GDP, became a haven for quasi-entrepreneurship and inefficiency. Like many other European coun- 
tries, the Czech Republic is engaged in a process of patching up its social system and postponing genuine reforms. If the Czech society is to avoid slipping into stagnation, it should take the next logical step: institutional changes that open up nontraded and government sectors to authentic entrepreneurship, while retaining regulation over them where the public interest is concerned. Unfortunately, in this case the drivers of change cannot be expected to come from the European Commission, as they did in the transformation of the traded sector prior to EU accession. This time the forces of change must be found inside the country.

As Pejovich has argued [1994], the main objective of privatisation should be seen in creating the free market for institutions and for incentives supporting property rights, that is, in shaping the demand for institutions supporting productivity. From this perspective, the wrangle over capital transfers in 1991-1996 was an unavoidable detour prior to more substantial changes. There were too many vested interests to avoid such a chaotic prelude. It was only in East Germany where the transition was orchestrated from the outside and the attempt at transition without detours turned into a failure. The stage of social tâtonnement and that of the subsequent establishment of new market-enhancing institutions cannot be merged. Ultimately, as Loužek concluded [2005], there was hardly any alternative to the government strategy of the Czech transition, even though its many institutional tactics could have been streamlined, thus mitigating the extent of its schizophrenia, frauds and dead ends by providing more rules and information.

The class of elite entrepreneurs has developed gradually. Societies are locked in the flow of history, culture and ideology, and it takes time to disentangle the traps of transition, the evolution of which is an extremely demanding process that cannot be tackled by an 'enlightened' central command. In the Czech case the present evolution of entrepreneurship got stuck two-thirds of the way along. It should continue in the sectors still under the control of the bureaucracy. Reforms of the public sector through the introduction of market institutions and managerial methods drawn from the corporate world would be the natural finale of the entire transition.

Although the transformation of the new EU member countries is reaching an end, the topic of peaceful social transition is still new and has not yet been sufficiently examined. In addition, it is complicated by many local specifics that prevent a universal analysis. Transition processes will continue to occur in many other societies around the world. In another article by this author (see [Benáček 2006]) there was an attempt to apply the experiences from Central Europe to the Cuban potential transition. We could also imagine that new approaches to transition will have to be undertaken in Iraq and that societies of Iran, North Korea, or Afghanistan should consider them, too, and compare such evolution with alternatives based on force. The unexpected economic take-off in China or India cannot be explained dissociated from the gradual strategies to transition taken there. Even the EU-27 should think about implementing gradual but fundamental changes in order to master the transition to viable and effective social governance in its member states. 


\section{Conclusion}

This article presents an attempt to explain the post-communist transitions as a sequence of logical steps within gradual social processes. They emerged out of the legacies of both pre-war capitalism and the jugglery of communist management. Together these influences became the seeds of entrepreneurial activity and of the aspirations of transformation into authentic entrepreneurship. Three crucial steps were required, which pre-determined the peaceful nature of the transition:

a) The launching of the transition at a moment when the communist elite (nomenklatura) was under no direct external threat and when it had accumulated sufficient social and human capital to be able to withstand the pressure of domestic opposition.

b) The initiation of ensuing processes of gradual social, economic, and political adjustments, offering opportunities to all, where the social (relational) capital of elites could be transformed into the ownership of economic capital. The various forms of mass privatisation without sufficiently performing property rights and economic institutions served that purpose.

c) The re-privatisation process and widespread bankruptcies, when competition was firmly established and solid property rights were in effect and when the advantages in human or entrepreneurial capital over-rode the importance of social capital. Only then was it possible for a competent new indigenous entrepreneurial class to emerge.

The aim here was to use the Czech experience to shed light on why the early stages of transition in all post-communist societies offered so many opportunities to the nomenklatura and why that process was partially reversed later on, especially in the EU accession countries. As a policy recommendation, the transition should refrain from the direct confrontation of adversaries. Instead of some centralised intervention, the conflicts should be re-directed to negotiable adjustments at microsocial levels. A unique combination of gradual change and the rapidly progressing stages of transition, heading towards the creation of new entrepreneurial elites, led society towards a new equilibrium, with fast growth and social order. The lessons from the peaceful, fast and effective transitions in the countries of Central and Baltic Europe, despite their peregrinations and trials and errors in human confrontations enrich the history of the development of capitalism and can be used to contemplate similar transitions in other societies.

VLADIMÍR BENÁČEK is a reader in international economics at Charles University and a researcher in the Department of Economic Sociology at the Institute of Sociology, Academy of Sciences of the Czech Republic in Prague. His specialisation covers topics such as international trade, economic integration, the behaviour of producers, competitiveness, and transition and institutional economics. His publications are available for downloading at http://ceses.cuni.cz/benacek/publications.html. 


\section{References}

Akerlof, G. 1970. 'The Market for Lemons.' Quarterly Journal of Economics 84: 488-500.

Baumol, W. J. 1990. 'Entrepreneurship: Productive, Unproductive and Destructive.' Journal of Political Economy 98: 893-921.

Benáček, V. 1994. 'The Rise and the Obstacles to Authentic Entrepreneurship during Transition: The Case of the Czech Private Businesses.' Working Papers 53. Prague: CERGE-EI. Available from <http://ceses.cuni.cz/Benacek/BERLIN\%20SME.pdf>.

Benáček, V. 1995. 'Entrepreneurship in Transition.' East European Journal of Economics 33 (2): 38-75.

Benáček, V. 2001. 'The Generic Private Sector in an Economy of Transition: Developments and their Impact on the Czech Economy.' Interim Report 46. Laxenburg: IIASA. Available from <http://www.iiasa.ac.at/Publications/Documents/IR-01-046.pdf >.

Benáček, V. 2003. 'Historical Perspectives of Growth, Integration and Policies for Catching Up in Transition Countries.' Prague Economic Papers 12 (1): 3-17.

Benáček, V. 2006. 'Political Economy of Re-integrating Cuba into the World Economy.' Paper presented at the Arnoldshain Seminar 'The EU and Latin America' in Vienna.

Benáček, V. 2007. 'On the Origins of the Czechoslovak Entrepreneurship.' Charles University, Working Papers of CESES, Prague: CESES. Available from $<$ http://ceses.cuni.cz/Benacek/Origins.pdf $>$.

Bezemer, D., U. Dulleck and P. Frijters. 2003. 'Socialism, Capitalism and Transition Co-ordination of Economic Relations and Output Performance.' Working Papers 305. Vienna: University of Vienna.

Blanchard, O. and M. Kremer. 1997. 'Disorganization.' Quarterly Journal of Economics 112 (4): 1091-1126.

Bourdieu, P. 1985. 'Forms of Capital.' Pp. 241-258 in Handbook of Theory and Research in the Sociology of Education, edited by J. Richardson. New York: Greenwood Press.

Coase, R.H. 1960. 'The Problem of Social Cost.' Journal of Law and Economics 3: 4-18.

de Ménil, G. and M. Maurel. 1993. Trading with Neighbours in Turbulent Times: Lessons from the Break-up of the Austro-Hungarian Empire in 1919. Paris: Delta.

Djankov, S. 1999. 'The Restructuring of Insider-dominated Firms.' Economics of Transition 7 (2): 467-485.

Eswaran, M. and A. Kotwal. 1989. 'Why Are Capitalists the Bosses.' Economic Journal 99: 162-176.

Eyal, G., I. Szelényi and E. Townsley. 1998. Making Capitalism without Capitalists. The New Ruling Elites in Eastern Europe. London: Verso.

Gábor, I.R. 1996. ‘Too Many, Too Small: Small Entrepreneurship in Hungary - Ailing or Prospering?' Pp. 148-165 in Restructuring Networks in Post-Socialism, edited by G. Grabher and D. Stark. Oxford: Oxford Univ. Press.

Hayek, F. A. 1935. Collectivist Economic Planning. London: Routledge.

Jones, R. and P. Kenen. (eds.) 1984. Handbook of International Economics. Vol. I. Amsterdam: North-Holland.

Kalecki, M. 1954. Entrepreneurship, Capital and Investment. Selected Essays on the Dynamics of the Capitalist Economy. Cambridge: Cambridge University Press.

Kornai, J. 1980. Economics of Shortage. Amsterdam: North-Holland.

Kornai, J. 1992. The Socialist System. Oxford: Oxford University Press.

Kornai, J. 2005. 'The Great Transformation of Central Eastern Europe: Success and Disappointment.' Economics of Transition 14: 207-244.

Laki, M. and J. Szalai. 2006. 'The Puzzle of Success: Hungarian Grand Entrepreneurs at the Turn of the Millennium.' Occasional Papers 75. Princeton: East European Studies.

Leibenstein, H. 1995. The Supply of Entrepreneurship. New York: Oxford University Press. 
Loužek, M. 2005. 'Nazrál čas k vyváženému hodnocení české privatizace?' (Has the Time Arrived for a Balanced Assessment of Czech Privatisation?) Politická ekonomie 53 (2): 147-162.

Machonin, P., M. Tuček, P. Hartoš and M. Nekola. 2006. ‘České ekonomické a politické elity po 15 letech postsocialistické transformace.' (The Czech Economic and Political Elites Fifteen Years into the Post-socialist Transition) Pp. 39-70 in České elity po patnácti letech transformace, edited by M. Tuček. Prague: Sociologický ústav AV ČR.

Machonin, P., M. Tuček and M. Nekola. 2006. 'The Czech Economic Elite after 15 Years of Post-socialist Transition.' Sociologický časopis/Czech Sociological Review 42 (3): 537-556.

Maskin, E. and C. Xu. 2000. 'Soft Budget Constraint Theories.' Economics of Transition 9 (1): $1-28$.

Matèjü, P. 1993a. Determinants of Economic Success in the First Stage of the Post-communist Transformation. The Czech Republic 1989-92. Pracovní texty/Working Papers 93:5. Prague: Sociologický ústav AV ČR.

Matějů, P. 1993b. 'Revolution for Whom? Analysis of Intra-generational Mobility in 1989-92.' Czech Sociological Review 1 (1): 309-325.

Matějů, P. and N. Lim. 1995. 'Who Has Gotten Ahead after the Fall of Communism? The Case of the Czech Republic.' Czech Sociological Review 3 (2): 117-136.

Matějů, P. 1997. 'Elite Research in the Czech Republic.' Pp. 61-76 in Elites in Transition. Elite Research in Central and Eastern Europe, edited by H. Best and U. Becker. Opladen: Leske und Budrich.

Matějů, P. and A. Vitásková. 2006. 'Interpersonal Trust and Mutually Beneficial Exchanges.' Sociologický časopis/Czech Sociological Review 42 (3): 493-516.

Matějů, P., O. Schneider and J. Večerník. 2003. Proč tak těžko... (Why So Hard?) Prague: Institute for Social and Economic Analyses.

McMillan, J. and C. Woodruff. 2002. 'The Central Role of Entrepreneurs in Transition Economies.' Journal of Economic Perspectives 16 (3): 153-170.

Mlčoch, L. 1990. 'Behaviour of the Czechoslovak Enterprise Sector.' Research Paper 384. Prague, Economic Institute, Academy of Sciences.

Možný, I. 1991. Proč tak snadno... (Why So Easy?). Prague: Sociologické nakladatelství.

Pejovich, S. 1994. 'The Market for Institutions vs. Capitalism by Fiat: The Case of Eastern Europe.' Kyklos 47: 519-529.

Pratt, J. and R. Zeckhauser (eds.). 1985. Principals and Agents: The Structure of Business. Boston: Harvard University Press.

Samuelson, P.A. 1967. Economics. 7th Edition. New York: McGraw Hill.

Sato, T. 1995. 'How Extensive Has the "Transition to Market Economy" Been?' Most 1: 4-18.

Selowsky, M. and P. Mitra. 2002. Transition: The First Ten Years. Lessons and an Agenda for Policy. Washington: The World Bank.

Sik, E. 1993. 'Network Capital in Capitalist, Communist and Post-communist Countries.' Pp. 173-192 in Networking in the Global Village, edited by B. Wellman. Boulder: Westview Press.

Tuček, M. (ed.) 2006. České elity po patnácti letech transformace. (Czech Elites after Fifteen Years of Transformation) Prague: Sociologický ústav AV ČR.

Večerník, J. 1996. Markets and People. The Czech Reform Experience in a Comparative Perspective. Aldershot: Avebury.

Winiecki, J. 2000. 'Crucial Relationship between the Privatized Sector and the Generic Private Sector in Post-Communist Privatization.' Communist and Post-Communist Studies 33: 505-515.

Winiecki, J., V. Benáček and M. Laki. 2004. The Private Sector after Communism. New Entrepreneurial Firms in Transition Economies. New York: Routledge. 